\title{
IJBE
}

International Journal of Business Economics, 1(1), 76-86, September 2019 http://jurnal.umsu.ac.id/index.php/ijbe

eISSN 2686-472X

ORIGINAL ARTICLE

\section{Effect of Financial Literacy and Lifestyle of Finance Student Behavior}

\author{
Ade Gunawan*, Chairani
}

\begin{abstract}
This study aims to examine the relationship between financial literacy and financial behavior of the lifestyle of the student and determine differences in financial literacy, lifestyle and behavior of student finance and business economics faculty. This research is quantitative data collection techniques using questionnaires. Sample used were 100 students consisting of students of the faculty of economics and business Muhammadiyah University of North Sumatra, this study uses judgment sampling. Data were analyzed using classical assumption test, multiple linear regression, $\mathrm{t}$ test, $\mathrm{F}$ test, and the coefficient of determination. Research shows that financial literacy has no effect on the financial behavior.
\end{abstract}

Keywords: Financial Literacy, Lifestyle, Behavioral Finance

DOI : https://doi.org/10.30596/ijbe.v1i1.3885

JEL Classification : G4, G53

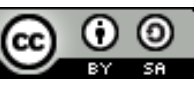

Published by IJBE, Indonesia | Copyright (C) 2019 by the Author(s) | This is an open access article distributed under the Creative Commons Attribution License http://creativecommons.org/licenses/by/4.0), which permitsunrestricted use, distribution, and reproduction in any medium, provided the original work is properly cited.

Cite this article as:

Gunawan, A., \& Chairani. (2019). Effect of Financial Literacy and Lifestyle of Finance Student Behavior. International Journal of Business Economics (IJBE), 1(1), 76-86.

Fakultas Ekonomi dan Bisnis, Universitas Muhammadiyah Sumatera Utara Jalan Kapten Mukhtar Basri No 3 Medan, North Sumatra, Indonesia

*Corresponding Author: adegunawan@umsu.ac.id 


\section{IJBE}

International Journal of Business Economics, 1(1), 76-86, September 2019

http:/ /jurnal.umsu.ac.id/index.php/ijbe

eISSN 2686-472X

\section{INTRODUCTION}

In the 20th century financial development is rapidly increasing, and conducted scientific research about finance, it indicates that the financial professions to be able to digest the development of new theories, including teachers, professors, student finance, businesses continue to acquire new theories, and this continues to grow, rapid changes occurring in the financial have profound implications for business education, especially the development of the theory of strong theory (ZL Antoni). The financial behavior starts from a person's behavior in the decision making process, responsible financial behavior should be owned by every individual, family well-managed society.

Survey Word Bank (2011), proved that low income earners do not need the services of banking products, is due to some conditions including funds owned not enough, plus yet got employment (unemployment), second, there's no advantage when it comes to banking, does not require credit, no collateral for loans in banks, yet have abbility for paying credit, they do not trust the banks to manage finances, do not have knowledge of banking products, considers expensive administrative costs. Naturally these conditions cause people to fail in achieving financial inclusion in low-income communities.

Indonesian financial regulators in this regard is the Financial Services Authority (FSA) has conducted research to determine the level of financial literacy in Indonesia, the FSA survey results suggest that the $12.84 \%$ of the total population of Indonesia is still relatively well literate including having knowledge of the existence of financial services, features, benefits, risks, rights and obligations related to financial services, and has the skills to use financial services products.

Based on data from the publication of the results of the Financial Services Authority (FSA), the financial literacy index of Indonesian society based on the work in 2016 for a group (cluster) Student / Student ie 23.4\% composite, conventional 23.2\%, and 5.3\% of sharia. Furthermore, based on age in 2016 to $18-25$ cluster was taken due to adjust to the age of students in general, financial literacy for the composite index of $32.1 \%$, a conventional $32.0 \%$, and $8.1 \%$ of sharia. Then, seen from the 2016 financial litearsi index per province terkhususnya people of North Sumatra, namely $31.3 \%$ for the composite, the conventional $31.3 \%$, and $5.5 \%$ for sharia. So the 2016 Financial Literacy index per provinceby Strata area is particularly Terrain $35.5 \%$ with better understanding on financial literacy.

Kusuma (2014) explained that Indonesia has a level of financial literacy are much lower compared to other countries such as Singapore, Malaysia and Thailand, the level of financial literacy community in Malaysia has reached lift 66\%, Singapore 98\%, and Thailand reached $73 \%$, while for Indonesia still reached $28 \%$, this is due to people not yet entirely familiar with financial services.

Empirical evidence, occurring in students as the research Chen \& Volpe (1998), Bestari (2012), the level of financial literacy of students is still very low, because they are not fully get education of personal finance at the University, it was found that the behavior of saving, investing, planning emergency fund and budgeting funds for the future has not been a primary choice or in other words, students do not have awareness about financial literacy, so that students tend to be consumptive.

Lifestyle describes the "whole person" who interacts with their environment. Lifestyle is a pattern of life that is expressed in activities, interests, and opinions in spending money and allocate time he had. 


\section{IJBE}

International Journal of Business Economics, 1(1), 76-86, September 2019

http://jurnal.umsu.ac.id/index.php/ijbe

eISSN 2686-472X

The phenomenon that occurs in the observations in this study giving out the impression that students tend to live a modern, hedonism, and this is reflected in the behavior of the daily life of students, habits of luxury living to follow the life style of course caused by the level of understanding financial literacy of students are still not optimal and have not been efficient in financial management.

The main factors forming the lifestyle can be divided into two: the demographic and psychographic. Demographic factors, for example, are based on the level of education, age, level of income, and sex, whereas psychographic factors are more complex because the indicators of their formation are of individual characteristics. This causes the students to imitate the behavior committed by him.

With a high lifestyle make financial behavior is also a picture of how people behave when faced with financial decisions that must be taken. Someone who is able to take decisions in managing finances will not have trouble in the future and demonstrate healthy behaviors so as to determine priorities on what needs and wants (Chinen \& Hideki, 2012).

Behavioral financeis a person's ability to organize, manage, plan and keep daily financial hari. Nababan and Sadalia, (2012) financial behavior relates to how people treat, manage, and use financial resources available to him. Individuals who have a responsible fiscal behavior tends to be effective in using the money he has, such as making a budget, save money, control spending, investing and paying obligations are timely.

According to research Sumtoro and Anastasia, (2015) states that "Behavioral finance is an approach that explains how humans make an investment or finance-related activities are influenced by psychological factors". According Sari, (2015), the factors affecting the financial behavior is as follows: 1) Learning in college, learning in higher education directly affects a person's level of financial literacy. In its activities, the universities provide courses, training, workshops, and discussion forums for students. 2). Family financial education, Students, like to imitate parents and bring habits in childhood to adulthood, including financial problems.

According to research Nababan and Sadalia, (2012) he argued indicators financial behavior is as follows: 1) Pay your bills on time, 2) Make expenditures and expenditures, 3) Record spending and spending (daily, weekly, monthly, and etc.), 4) Provide funds for unexpected expenses, 5) Saving periodically, 6) Compare prices between stores or supermarkets or supermarket before deciding to make a purchase.

Financial literacy include the ability to discern financial choices, discuss money and financial issues without discomfort, plan for the future, and respond competently to life events that affect everyday financial decisions, including events in the economy. According studies Financial Services Authority ( FSA) in the journal Tsalitsa, (2016) states that: "financial Literacy is a series of processes or activities to improve knowledge, skills , confidence of consumers and the public at large so that they are able to manage your personal finances better".

Furthermore, according to the OECD study Atkinson, (2012) states that: Financial Literacy is a "combination of awareneness, knowledge, skills, attitude and Behaviors Necessary to Make sound financial decisions and individual Ultimately Achieve financial wellbeing". Generally, it can be interpreted as a combination of the awareness, knowledge, skills, attitudes, and behaviors needed to make sound financial decisions and ultimately achieve individual financial well-being. According to Shim, et al., (2010), there are several factors that affect the Financial Literacy is as follows: 1) The social environment, 2) The behavior of the parents, 3) Financial education, 4) experience of the individual against the finance.

According to Widayati (2012) As for the indicators Literacy Finance is as follows: 1) Finding choices in his career, 2) Understanding the factors that influence the net salary, 3) 


\section{IJBE}

International Journal of Business Economics, 1(1), 76-86, September 2019

http:/ /jurnal.umsu.ac.id/index.php/ijbe

eISSN 2686-472X

Know the sources of income, 4) Explain how to achieve prosperity and meet financial goals, 5) Understand the budget saving, 6) Understanding insurance, 7) Analyzing the risk, return and liquidity, 8) Evaluate investment alternatives, 9) to analyze the effect of taxes and inflation on investment returns, 10) to analyze the advantages and losses in debt, 11) Describe the purpose of the track record of credit and recognize the rights of the debtor, 12) Describe ways to avoid or fix the debt problem, 13) Knowing the basic laws for consumer protection in the credit and debt, 14) able to make financial records, 15) Understand the balance sheet, profit and loss and cash flow.

Lifestyle is a description of behavior, a pattern of life that is expressed in activities, interests and opinions in spending money and how to allocate his time. According to the study Kotler (2002) in the journal Susanto, $(2013$, p.1) states that: Lifestyle is a pattern of life in the world expressed in activities, interests, and opinions, in a general sense that one's lifestyle can be seen from routine which he did, what they think about everything around him and how much he cares about it and also what he thinks about himself and the outside world.

Then proceed with the research and Minor, (2002) in the journal Rahayu and Alimudin (2015) states that: Lifestyle is to show how people live, how to spend the money, and how to allocate time. It can be concluded that a sedentary lifestyle is a pattern of life that is expressed in activities, interests, and opinions in spending money and how to allocate time. Nugraheni (2013) said that the factors that affect a person's lifestyle there are two factors which are derived factor from within the individual (internal) and factors that come from outside (external). Internal factors: 1) The attitude, 2) experience and observation, 3) Personality, 4) The concept of self, 5) Motif, and 6) Perception. The external factors include the group 1) Reference 2) Family. According to the study Joseph Plumer (1974) said segmentation lifestyle measure of human activities in terms of: 1) Activities, 2) interest, 3) A person's image of self and others, and 4) the basic characters.

\section{RESEARCH METHODS}

This research is a quantitative and nature explanatory research, Which is a notch research menejelaskan each variable studied and the relationship between the variables (Sugiyono, 2008).

This research was conducted at the Faculty of Economics and Business UMSU. The population is the target of students of the Faculty of Economics and Business UMSU Semester 5 and 7 are boarding as many as 100 students usejudgment sampling, Data collection techniques using a questionnaire (Questionnaire). Methods of data analysis used in this study to fulfill the purpose of proving the hypothesis is statistically classical assumption test, multiple linear regression, t-test, F-test and coefficient of determination with SPSS version 22.0

\section{RESULTS AND DISCUSSION Results}

For the implementation of the regression classic assumption test is performed to detect whether there is any deviation from the assumptions on regression. The requirements for testing classical assumptions include normality test, multicollinearity test, and heteroscedasticity test. The purpose of the data normality test done to see if the regression mpdel dependent and independent variables have normal or not normal distribution. Conditions of testing, if the data spread around the diagonal line and follow the direction of the diagonal line of the regression model to meet the assumption of normality. In principle can be detected in view of the spread 


\section{IJBE}

International Journal of Business Economics, 1(1), 76-86, September 2019

http://jurnal.umsu.ac.id/index.php/ijbe

eISSN 2686-472X

of data (dots) on a diagonal on Normal Test P- Residual Plots Of Regression Stadardized, Kolmogorov, and a histogram graph.

Normal P-Plot Of Regression Standardized Residual Test on this research can be seen based on the following figur:

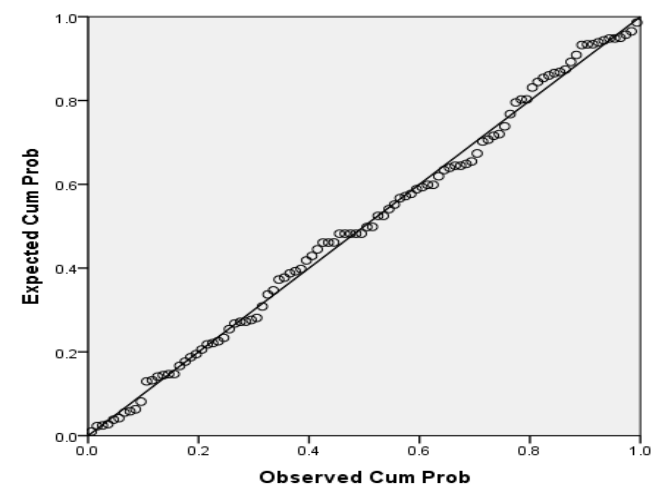

Figure 1: Normality Test P-Plot Standardized

In Figure 1 above shows the standardized cendreung PP plot follows the diagonal line in identifying that normality testing regression model in this study had to meet the assumptions noted previously, so that the data in this regression model with normal distribution.

Test is intended that this research can determine whether or not the variable indevenden berdistribusinormalatau the dependent variables or both. 1) If a significant number of $>0.05$, the data has a normal distribution, 2) If significant figures $<0.05$ then the data does not have a normal distribution.

Table 1. Kolmogorov-Smirnov Normality Test

One-Sample Kolmogorov-Smirnov Test

\begin{tabular}{llr}
\hline & & \multicolumn{1}{c}{$\begin{array}{c}\text { Unstandarized } \\
\text { residual }\end{array}$} \\
\hline $\mathrm{N}$ & mean & 100 \\
Normal Parameters, b & Std. deviation & .0000000 \\
& Absolute & 2.38678126 \\
Most Extreme Differences & positive & .045 \\
& negative & .044 \\
Test Statistic & & .045 \\
Asymp. Sig. (2-tailed) & .045 \\
\hline a. Test distribution is Normal. & $.200 \mathrm{c}, \mathrm{d}$ \\
\hline
\end{tabular}

The results of data processing in Table 1 obtained by the value of the Kolmogorov Smirnofadalah significant 0,045 and at 0.200 which means a significant value greater than 0.05 then the data were normally distributed residuals. This is also supported by the histogram graph where the data follows the diagonal line. This graph normality can be seen in the following figure. 


\section{IJBE}

International Journal of Business Economics, 1(1), 76-86, September 2019

http://jurnal.umsu.ac.id/index.php/ijbe

eISSN 2686-472X

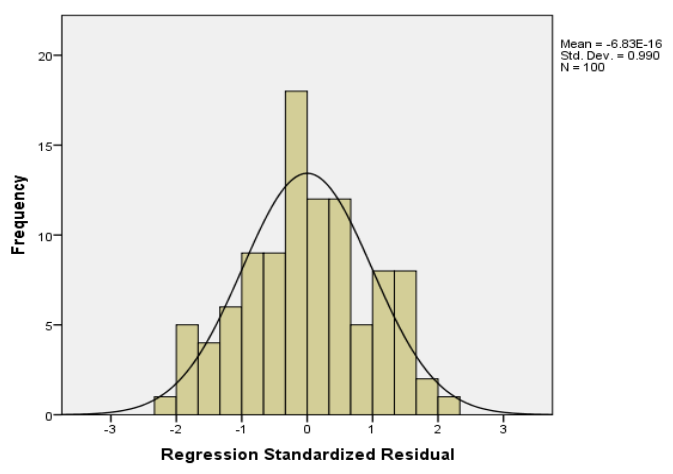

Figure 2: Graph Histogram Normality Test

A histogram is a bar graph can be used to test (graphical) is a normally distributed data or not. If the normal distribution of data, the data will be membentung sort of bell. If the data graph looks far from a bell shape, it can be said the data are not normally distributed. In the picture above it can be seen that the histogram graph showing a normal distribution. Because it has a tendency impartial curve and a bell-shaped curve that is almost perfect.

Testing multicoloniarity research variables through independent test calculations can be seen between independent variables and statistical analysis results collinearty. Multicollinearity has the objective is to see whether the high correlation variables were not the case, it is necessary to do hypothesis that is accepted $H_{0}$ if $\mathrm{VIF}<10$ and a tolerance of close to 1 , and rejected if $\mathrm{VIF}>10$ and the tolerance value is close to 0 . interpedensi test results between the variables in this study can be seen in the following table: $H_{0}$

Table 2. Results Multicoloniarity Coefficients

\begin{tabular}{llcc}
\hline & & \multicolumn{2}{c}{ collinearity statistic } \\
Model & & tolerance & VIF \\
\hline 1 & Financial literacy & .989 & 1,011 \\
& Lifestyle & .989 & 1,011 \\
\hline
\end{tabular}

a. Dependent Variable: financial behaviour

Data multicoloniarity test table above can be understood that two independent variables namely Financial literacy (X1) and Lifestyle (X2) has a statistical collinearity VIF value of 1.011. This value can be interpreted within the tolerance limits that have been determined where all the variables near the numbers 1 and VIF is less than 10, so it can be concluded not happen multicoloniarity in the independent variable of this research.

The heteroscedasticity test in this study supports to see whether the variables have the same variant or not. Heteroscedasticity has one observation that another observation is different. The assessment results will be less than they should be. Fundamental analysis of heteroscedasticity data research in this study is as follows: If certain patterns such as dots form specific regular patterns (widening, spreading then narrowing), then heteroscedasticity has occurred. If there is no clear pattern and the points of distribution above and below the number 0 on the Y-axis, then there is no heteroscedasticity. 


\section{IJBE}

International Journal of Business Economics, 1(1), 76-86, September 2019

http:/ /jurnal.umsu.ac.id/index.php/ijbe

eISSN 2686-472X

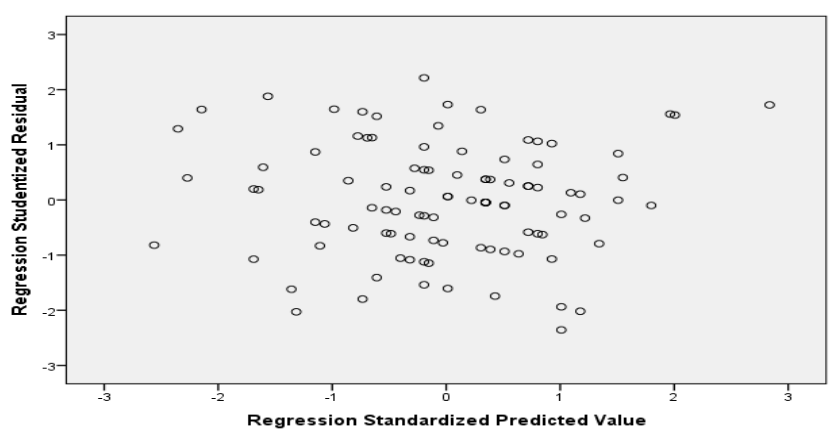

Figure 3. Scatterplot Test heteroscedasticity

Figure 3, scatter plot can be seen that the variables in this study is based on test data heterokedastisitas can be interpreted that the absence occurs heteroscedasticity used in the study variables. For there is no clear pattern as well as the points spread above and below the number 0 on the $\mathrm{Y}$ axis, So that it can be said heteroskedasticity test on this research variable can be fulfilled. Variable data used in this study can be used for further testing.

\section{Multiple Linear Regression}

The results of data processing using SPSS on multiple regression analysis on Financial Literacy (X1) and Lifestyle (X2) to Perilaku Keuangan (Y) on the faculty of Economics and Business student UMSU it can be seen the following table:

Table 3. Multiple Linear Regression

\begin{tabular}{|c|c|c|c|c|c|c|}
\hline \multirow{2}{*}{\multicolumn{2}{|c|}{ Model }} & \multicolumn{2}{|c|}{$\begin{array}{l}\text { Unstandarized } \\
\text { Coefficients }\end{array}$} & \multirow{2}{*}{$\begin{array}{c}\begin{array}{c}\text { standardized } \\
\text { Coefficients }\end{array} \\
\text { beta }\end{array}$} & \multirow[b]{2}{*}{$\mathrm{T}$} & \multirow[b]{2}{*}{ Siq. } \\
\hline & & $\mathrm{B}$ & Std. Error & & & \\
\hline \multirow[t]{3}{*}{1} & (Constant) & 12265 & 3,765 & & 3,258 & .002 \\
\hline & Financial literacy & .225 & .124 & .176 & 1,812 & .073 \\
\hline & Lifestyle & .161 & .066 & .236 & 2,428 & .017 \\
\hline
\end{tabular}

a. Dependent Variable: financial behaviour

This acquisition of the equation above shows that all independent variables financial literacy (X1) and Lifestyle (X2) has a coefficient that is positive, with the sense that all independent variables in this study have a relationship and influence the direction of the variable $\mathrm{Y}$ (financial literacy), assuming that financial literacy variable coefficient (X1) gives a value of 0.225 , which means that if the knowledge to do well, assuming other variables remain, maka financial literacy will increase. So is the coefficient Lifestyle (X2) gives a value of 0161 which means that if the trust is well done with the assumption that other variables constant, the Lifestyle will increase.

\section{Hypothesis test}

\section{Partial test (Test - t)}

Testing the hypothesis on t-test statistical test is basically aimed to show how far the level of the relationship and the influence of the independent variables individually in explaining the dependent variable in this study. The hypothesis testing using the Statistical Program For Social Sceiences (SPSS) can be seen in the following table: 


\section{IJBE}

International Journal of Business Economics, 1(1), 76-86, September 2019

http://jurnal.umsu.ac.id/index.php/ijbe

eISSN 2686-472X

\begin{tabular}{|c|c|c|c|c|c|c|}
\hline \multirow{2}{*}{\multicolumn{2}{|c|}{ Model }} & \multicolumn{2}{|c|}{$\begin{array}{l}\text { Unstandarized } \\
\text { coefficinents }\end{array}$} & $\begin{array}{c}\text { standardize } \\
d \\
\text { Coefficients } \\
\end{array}$ & \multirow[b]{2}{*}{$\mathrm{t}$} & \multirow[b]{2}{*}{ Sig. } \\
\hline & & $\mathrm{B}$ & Std. Error & beta & & \\
\hline 1 & (Constant) & 12265 & 3,765 & & 3,258 & .002 \\
\hline & $\begin{array}{l}\text { Financial } \\
\text { literacy }\end{array}$ & .225 & .124 & .176 & 1,812 & .073 \\
\hline & Lifestyle & 161 & .066 & .236 & 2,428 & .017 \\
\hline
\end{tabular}

\section{Effect of Financial Literacy (X1) on Financial Behavior (Y)}

Based on the test results in table 4 the influence of social capital variables (X2) on financial inclusion $(\mathrm{Y})$ is obtained $t_{\text {tabe }}$ amounted to 1,812 and the obtained value $=2.428$ meaning that $>$ with a value of $0.073>0.05$. These results can be concluded that acceptable. This shows that the influence of financial literacy variable $(\mathrm{X})$ to Financial Behavior $(\mathrm{Y})$ on UMSU student.

\section{Effect of Lifestyle (X2) on Financial Behavior (Y)}

Based on the test results in table 4 Lifestyle influence of variables (X2) to Financial Behavior (Y) is obtained $t_{\text {tabel }}$ amounted to 1,984 and the obtained value $=2.428$ meaning that $>$ the significant value of $0.017>0.05$. These results can be concluded that it was rejected. This shows that the influence of the variable Lifestyle (X2) to Perilaku Keuangan (Y) on UMSU student.

\section{Simultaneous Test (F-test)}

The test statistic $\mathrm{F}$ test (simultaneous) is performed to determine whether the independent variables together have a significant effect or not on the dependent variable.

Table 5. Simultaneous Significant test (test - F)

\begin{tabular}{llrrrrr}
\multicolumn{7}{c}{ ANOVA } \\
\hline Model & & Sum of Squares & df & mean Square & \multicolumn{1}{c}{ F } & Sig. \\
\hline 1 & Regression & 59464 & 2 & 29732 & 5114 & $.008 b$ \\
& residual & 563976 & 97 & 5,814 & & \\
& Total & 623440 & 99 & & & \\
\hline
\end{tabular}

a. Dependent Variable: finansial behaviour

a. Predictors: (Constant), Lifestyle, financial literacy

Based on $\mathrm{F}$ test table data table 5 with the above criteria obtained value $F_{\text {hitung }}$ amounting to $5.114>$ value of $3.09(\mathrm{DF} 1=\mathrm{k}$; nk) $=\mathrm{F}(2: 98)$ or a significant $<0.05$ so that it can be understood that there are significant is a simultaneous between the independent variable $(\mathrm{X})$ on the dependent variable $(\mathrm{Y}) \cdot F_{\text {tabel }} 0.008^{b}$

Was conducted to determine the amount of determination coefficient values indicate large variations in the dependent variable that can be explained by the variable independenya. The coefficient of determination used to measure how far the independent variables used in this research in explaining the dependent variable. Value is determined by the value of the coefficient of determination $\mathrm{R}$ square as can be seen where the table below: 


\section{IJBE}

International Journal of Business Economics, 1(1), 76-86, September 2019

http://jurnal.umsu.ac.id/index.php/ijbe

eISSN 2686-472X

Table 6. Coefficient of Determination Model Summary

\begin{tabular}{llrrr}
\hline Model & $\mathrm{R}$ & R Square & $\begin{array}{c}\text { Adjusted R } \\
\text { Square }\end{array}$ & $\begin{array}{c}\text { Std. Error of the } \\
\text { Estimate }\end{array}$ \\
\hline 1 & $.309 a$ & .095 & .077 & 2.41126 \\
\hline A. Predictor
\end{tabular}

A. Predictors: (Constant), Lifestyle, financial literacy

Based on the test results of Table 6 regression coefficient of determination models in the table above summary it can be seen that eterminasi coefficient ( $\mathrm{R}$ square) obtained in this study amounted to 0.095 , this shows that $07.7 \%$ meaning financial literacy variable (X1) and Lifestyle (X2), The remaining portion of $92.3 \%$ can be explained by other variables not included in this study.

\section{Discussion}

\section{Effect of Financial Literacy on Student Financial Behavior}

Financial literacy has no effect on the financial behavior of students of the Faculty of Economics and Business UMSU were boarding. This means that financial literacy conducted by the student does not have a strong impact and significantly does notinfluence financial behavior change Faculty of Economics and Business UMSU were boarding. Based on the multiple linear regression analysis and test results obtained sig $0.073>0.05$, then the hypothesis is rejected. Therefore, financial literacy students are having no effect and significant impact on the financial behavior of students UMSU with great influence amounted to 0.124 or $12.40 \%$. Survey in this study provide data that the financial literacy of students included in either category or have a high tendency for their financial planning. The majority of respondents were 58\% strongly agree that the benefits of personal financial planning is to prepare financial needs and goals of the future. The results are consistent the research that has been conducted by the financial literacy level OJK, where the level of financial literacy that occurs in the community is still very low.

Furthermore this study are consistent with research Anggraeni (2016) which states that the level of financial literacy has no effect on the financial management resulting from lack of basic understanding of financial literacy tengtang.

\section{The Effect of Lifestyle on Student Financial Behavior}

Lifestyle proved positive and significant impact on the financial behavior of students of the Faculty of Economics and Business UMSU were boarding. This means that lifestyle by students have a strong impact and significantly affect the financial behavior of students of the Faculty of Economics and Business UMSU were boarding. Based on the multiple linear regression analysis of the $t$ test results obtained sig $0.017<0.05$ then the hypothesis is accepted. Therefore lifestyles by students have a positive and significant impact on the financial behavior of students with great influence amounted to 0,066 , or $6.60 \%$.

Survey in this study provide data that lifestyle boarding students who fall into the category is not well or have a high tendency to live in a high level of fun and enjoyment without thinking about the security and benefits for the future. The majority of respondents as many as $61 \%$ agree that the monthly income and revenue obtained from the parents. The results are consistent with research yang done by (Rahmawany, et al: 2018) which stated in his research 


\section{IJBE}

International Journal of Business Economics, 1(1), 76-86, September 2019

http:/ /jurnal.umsu.ac.id/index.php/ijbe

eISSN 2686-472X

that lifestyle positive and significant impact on the financial behavior of the students, this means a lifestyle that done by the students have a strong impact and significantly affect student financial behavior change.

The results of this study are consistent with research Wahyuningsih \& Fatmawati (2016), stated in his research that lifestyle affects positively and significantly related to the purchase without a plan, and the results of a survey of the lifestyle of respondents indicated that the students of the Faculty of Economics and Business UMSU the boarding more likely and used to have unplanned purchasing behavior.

\section{CONCLUSIONS}

The results of the analysis discussed above, it can be deduced as follows: 1) There is the effect of variable X1 (Financial Literacy) to variable Y (Behavioral Finance). These relationships contained the sense that the higher / better X1 (Financial Literacy), the higher the development of variable Y (Behavioral Finance) student UMSU, 2) There is an effect X2 (Lifestyle) to variable Y (Behavioral Finance). These relationships contained the sense that the higher / better X2 (Lifestyle), the higher the development of variable Y (Behavioral Finance) student UMSU, 3) There is an effect X1 (Literacy Finance) and X2 (Lifestyle) to variable Y (Behavioral Finance). These relationships contained the sense that the higher / better X1 (Financial Literacy) and X2 (Lifestyle).

There are some suggestions that should be considered in research on financial literacy, lifestyle and behavioral finance, which are as follows: 1) The study only focused analyze the impact of financial literacy and lifestyles of the financial behavior. further research could be added to other variables such as peers, pocket money, the family environment and the possibility of parental education also affect student financial behavior. This study only uses a sample on the faculty and the university just so it would likely be different if the research done elsewhere and use some of the faculty and the university then compare them, 2) subsequent research is highly expected as research on financial literacy, lifestyle and behavior of student finance is still very small in Indonesia. This study can then be used samples from various faculties and universities, and also add a variable to measure financial literacy, lifestyle and financial behavior of students, 3) Students are advised to always learn and sensitive financial information in order to have a financial literacy high enough so as to avoid of financial issues and financial literacy Indonesia can rise and is higher than other countries.

\section{REFERENCES}

Anita Sari, Dian. (2015). Financial Literacy and Financial Behavior of Students. Journals Studies $\quad$ Student Case STIE 'YPPI Rembang, 6 (1): 171-174.

Dwi Anggraeni, Birawani. (2016) Financial Literacy Levels .Pengaruh Own Effort Against Financial Management (Case Study: SMEs Depok). JurnalVokasi Indonesia , 4 (1): 48-49.

Juliandi, Azuar. Irfan, Saprinal Manurung. (2015). Research Methodology Bisnis.Medan: UMSU PRESS.

Kirgiz, Ayca. (2014). Hedonism, A Consumer's Disease Of The Modern Age: Gender And Hedonic Shopping in Turkey. Global Media Journal, 4 (8): 200- 212.

Novi Yushita, Amanita. (2017). Importance of Financial Literacy For Management Personal Finance, Nominal Journal, 6 (1): 13-14. 


\section{IJBE}

International Journal of Business Economics, 1(1), 76-86, September 2019

http:/ /jurnal.umsu.ac.id/index.php/ijbe

eISSN 2686-472X

Pulungan, Delyana Rahmawany. Koto, Murviana. and Syahfitri, Lena. (2018).

Lifestyle Against the hedonic and Emotional Intelligence

Behavioral

Influence

College student, Seminar NasionalRoyal (strings), 4-

5.

Finance

Rina, Rahayu and Alimudin, Throne. (2015). Pegaruh Education, Environment

Relationships and Lifestyle Behaviors Against Irregularities Work and

Family,

Finance (Empirical Study on Employee Division of Finance \&Accounting PT. Meratus Line). e-Journal Magistra Management Science, 1 (1): 4-5.

S. Soetiono, Kusumaningtuti and Setiawan, Cecelia. (2018). Literacy and Inclusion Finance Indonesia. Depok: PT RajaGrafindo Persada.

Susanto, Anga Sandy. (2013). Make Segmentation Based on Life Style (Style Life), JIBEKA Journal, 7 (2): 1-3.

Saufika, Anita. Retnaningsih. and Afiasari. (2012). Lifestyle and Habits Student meal. Journals Ilm.Kel \& Kons , 5 (2): 158-163.

Sugiyono. (2016). Quantitative Research Methods, Qualitative and R \& D. Bandung: Alfabeta.

Tsalitsa, Alina (2016). Effect Analysis of Financial Literacy and Demographic Factors Against Credit Decision At PT. Columbia Branch Holy. Journals Media Economics and Management, 31 (1): 4.

Drafting team. (2009). Thesis Writing Guide Faculty of Economics and Business Muhammadiyah University of North Sumatra. Field.

Wahyuningsih, Widowati. Fatmawati, Beautiful. (2016). The Influence Of Hedonic Lifestyle, Shopping Addiction, Fashion Involvement On Global Brand Impulse Buying. JBTI, 7 (2): 278-300.

Widayati, Irin (2012). Factors Affecting Financial Literacy Students of the Faculty of Economics dBusiness an Brawijaya University. Journals Accounting and Education,1 (1): 90-91. 